\title{
An Account of the Difference Between Women's Income Before and After Participating in the Self-Help Groups in Urban West Region of Unguja
}

\author{
Tabia Maulid Mwita ${ }^{1}$, Haroonah Nsubuga ${ }^{2}$, Abdalla Ussi Hamad ${ }^{3}$, Rukkaya Wakif Muhammed ${ }^{2}$ \\ ${ }^{1}$ Department of Public Administration, Zanzibar University, Zanzibar, Tanzania \\ ${ }^{2}$ Department of Public Administration, Faculty of Arts and Social Sciences, Zanzibar University, Zanzibar, Tanzania \\ ${ }^{3}$ Department of Economics, Faculty of Arts and Social Sciences, Zanzibar University, Zanzibar, Tanzania
}

\section{Email address:}

tabiamwitatz@gmail.com (T. M. Mwita),nsubugaharoonah@gmail.com (H. Nsubuga), abdalla.hamad@zanvarsity.ac.tz (A. U. Hamad), mamaatqa@gmail.com (R. W. Muhammed)

${ }^{*}$ Corresponding author

\section{To cite this article:}

Tabia Maulid Mwita, Haroonah Nsubuga, Abdalla Ussi Hamad, Rukkaya Wakif Muhammed. An Account of the Difference Between Women's Income Before and After Participating in the Self-Help Groups in Urban West Region of Unguja. International Journal of Sustainable Development Research. Vol. 7, No. 1, 2021, pp. 9-16. doi: 10.11648/j.ijsdr.20210701.12

Received: March 18, 2021; Accepted: April 12, 2021; Published: April 20, 2021

\begin{abstract}
The Self Help Group is becoming one of the most important social and economic activities of today's world and the Zanzibar Government has realized its potential especially for the women. Therefore, this study aimed at providing a candid account of the difference of women's income before and after participating in the self-help groups (SHGs) in Urban West Region of Unguja. Having adopted positivism as its philosophical assumption, the researchers mainly employed quantitative research approach which was the most appropriate method of analysis for this study. The sample size for this study consisted of 90 women who belong to the ten (10) self-help groups in Urban West Region of Unguja and survey questionnaire was used as data collection instrument. To achieve credible results, both descriptive (such as mean scores, standard deviation, frequencies and percentages) and inferential statistical techniques (t-test) were used to analyze the collected data from relevant respondents. The results indicated that, by using t-test, there was a difference in income before and after participation in the self-help groups. Last but not the least, SHGs if well managed, can be a viable tool of income generation to the poor and needy, government itself, community based organizations, nongovernmental organizations to help elevate the positions and financial status of their stakeholders, the women inclusive.
\end{abstract}

Keywords: Social Helps Groups, Annual Income, Women Participation, T-test, Urban West Region

\section{Introduction}

Economic empowerment can be explained in different angles such as encouraging participation in economic and production activities for raising economic condition; Economic empowerment can be in terms of agricultural activities, business and entrepreneurial initiatives [1].

In 2012, United Nations (UN) Women joined hand with World Food Programme (WFP), Food and Agriculture Organization (FAO) and International Fund for Agriculture Development (IFAD), they launch a joint programme to empower poor rural women through economic integration and food security initiatives [2]. More specifically, these initiatives intended to empower rural women to claim their rights to land, leadership and opportunities to make their life choices. Further, women would participate in shaping laws, policies and programmes.

According to Sarania [3], Beijing, China, Canada supported great women aiming at spending \$ 6.2 million covering 20062014 which was to benefit 14,000 women entrepreneurs across Philippines. Women's economic empowerment projects were the target. Building women's economic empowerment is a strong complement to Canada's objectives related to improving maternal, newborn and child health. According to Yssaad and Ferrao [4], Canadian economy between 2003 and 2012, grew up due to the number of self-employed women to 
the tune of $50 \%$ faster at $14 \%$ than the rate of male selfemployed men which was merely $9 \%$.

In developing countries and Tanzania has no exception, have been used the SHGs as a tools of emphasizing individuals to form networks as well as an institutions in which its members support one another. Effectively, these institutions have been used as vehicles of integrating individuals with the rest of the community by ensuring them better participation in different community activities. In addition to economic roles, these groups have been providing social ties, enhancing people's participation in the decision making processes and hence improving the quality of rural and urban life. They play a very important role in social change. In their design, the groups not only change the outer form of a community or a society but also the social institutions as well as ideas of the people living in the society. In other words, it also applies to change the material aspects of life as well as in the ideas, values and attitudes of the people [5].

Specifically, in Zanzibar, the self helps groups were mostly focuses on empowering women in community. To support this, most of the international donor funded and national development programmes have focused their attention on improving social and economic status through provision of education, employment, healthcare and involvement in social and economic institutions, including agriculture training and cooperative groups [6].

In additional, the SHGs in Zanzibar also have focused their activities on multidimensional arenas like micro credit, animal husbandry, community forests, social awareness, cultural activities, social and legal advocacy, eradication of social evils, literacy and vocational trainings and HIV/AIDS awareness [7]. These activities are expected to uplift the status of women in Zanzibar, but an empirical assessment to this statement is necessary to make this expectation valid. Not all SHGs are conducting all these activities at the same time. Since, every society is different also in terms of the social problems they have, SHGs have focused on the social problems that they are facing in their locality.

More importantly, SHGs in Zanzibar are dominating the informal sector and they are a common phenomenon. This is due to the nature of Zanzibar which is dominated by Islamic religion which emphasize people work together and helping one another. So, if they decide to make union/groups they are not waiting to be known formally they conducting their activities even they are not registered. Normally, these groups found in different categories basing on the purposes they were designed for, which among others include saving and credit associations, burial associations, business, farming and sports/entertainment group/organizations. These groups are important community institutions that offer a variety of products and services. However, the most important services/products offered by SHGs in Zanzibar are micro finance services. Fakih [6] found SHGs very relevant in uplifting and supporting the development agenda of women in Zanzibar since they are offering them a lot of financial support for their self-reliance

\section{Statement of the Problem}

Self Help Group is becoming one of the most important social and economic activities in the contemporary society. It involves movement of millions of people and improves economic situation, education, status and health conditions of the people. Due to many problems in SHGs like getting loans, savings and self-employment, majority of the Self Help Groups involve in these activities. All these show that, the SHGs have a large potential gain through the SHGs to the urban and rural women.

The number of SACCOS as part of SHGs in Zanzibar has increased, by December 2018, they were 29,187 members with contributions of TZS 14,712,558,293. TZs $20,382,783,801$ in loans were issued. In December 2015, Savings and Credit Unions grew up to 222 with 22,606 members (Unguja 16,250 and Pemba 6,356) placed shares, savings and deposits worth TZs 6.64 billion and loans worth TZs 6.86 billion. Currently, credit through the handset is worth almost like TZs 3.33 billion. In addition, groups 53 merged with SACCOS as part of SHGs, Unguja 47 and Pemba 6 [8].

However, for households of women belonging to such groups in the study area, their socio-economic status continues to register poor development indicators. This study therefore was designed to examine the income difference of women before and after participation in SHGs in Urban West Region of Unguja.

\section{Theoretical Review}

This study was governed by two theories in relation to social help groups for women. These were;

Social Network Theory: Social Network Theory formulated by Durkheim [9] is a social structure made of individuals called nodes which are tied by one or more specific types of interdependency, such as friendship, kinship, financial exchange, dislike, sexual relationships, or relationships of beliefs, knowledge or prestige. This theory views relationships in terms of nodes and ties. Nodes in this case could be individuals within the network and ties refer to the relationships between the individuals. Social Network Theory produces an alternative view, where the attributes of individuals are less important than their relationships and ties within the network [10].

Collective Action Theory: Collective Action Theory was first developed by Mancur [11]. He argued that, any group of individuals attempting to provide a public good had troubles to do so efficiently. On the one hand, individuals had incentives to "free-ride" on the efforts of others in certain groups and on the other hand, the size of a group is of high importance and difficult to optimally determine. The nature of women coming together voluntarily to form SHGs to foster their income levels, reduction of poverty, was a roadmap towards achievement of integrated and sustainable development in rural areas. Conflict theorists, structuralfunctionalists, economists and feminists are some of the 
leading voices in Collective Action

\section{Empirical Literature Review}

This part reviews the previous works conducted by various scholars in the field of socio help groups especially for women. Some of the scholars are:

Nayak and Panigrahi [12] researched widely and wrote extensively on women participation in Self- Help Group activities. They examined the impact of the level of participation in SHGs on the empowerment (economic, social and political) of women SHG members. Also they investigate the impact of moderating variables, such as socio-economic status, age and place of residence, on the relationship between the level of participation and empowerment. They used interview as the method of data collection and they interviewed 353 women SHG members from the eastern Indian State of Odisha. Through analysis stage, they used partial least squares structural equation modeling (PLS-SEM). The findings suggest that, an increased level of participation in SHGs results in enhanced economic empowerment of its members by bringing in employment opportunities, higher income, stability in current jobs and improved entrepreneurial abilities.

Joshi [13], in his study of analysis of women's self-help groups' involvement in microfinance program in India had found the following results. Primary data was gathered from women respondents only on factors relating to the ownership of assets, housing characteristics and other demographic details. Both SHG and non-SHG women members were chosen as key informants during the survey. The results showed that, factors including age, education, family type and distance from the market had a significant impact on the participation of women in SHGs. Also, there was a significant difference in both these values which suggested that, the value of the empowerment index got significantly increased after joining the SHGs.

Although, Alemu, Kempen and Ruben [14], dealt with women empowerment through Self-Help Groups: the Bittersweet Fruits of Collective Apple Cultivation in Highland Ethiopia. Impact was done on the basis of a crosssectional survey among SHG members and non-members, using propensity score matching. The results pointed towards positive and significant impact of SHG participation on empowerment at the community level, which suggested that, SHGs offered an effective space for women to share information and raise awareness about their rights.

Furthermore, Mbai [15], showed the influence of SelfHelp Groups activities on women empowerment in rural Kenya: A Case of Miambani Ward, Kitui County. The study used a descriptive survey research design and random sampling technique applied in selecting the study sample. Data summarized using descriptive statistics and statistically analysed by using SPSS method. In this study, the findings showed that, influence of self-help groups activities on empowerment of the women was far beyond letting them access loans; they are also developed socially and empowered politically. Also the study found that, most of the self-help group members got their money from their groups in form of table banking.

Moreover, Badejo et. al., [16], indicated the impact of selfhelp groups on pastoral women's empowerment and agency: A study in Nigeria. In-depth interviews were conducted at the household level with selected Fulani and Ron households in six villages in Bokkos LGA, Plateau State. Where 21 self-help groups (both male and female) were identified of which six were women's self-help groups. Two focus group discussions ( $n=6$ members for each FGD) were held with the representatives of all six women's self-help groups in the reserve. Findings showed that, groups promoting social, physical and psychological health strongly motivated women's involvement in self-help groups. Self-help activities showed commitment to effect a change in their livelihoods, despite constraining environmental, cultural and social factors.

Okello [17], investigated women's Self Help Groups: A Study of their Characteristics and Performance in Saboti Constituency, Trans-Nzoia County. The study used a case study design and data was gathered through semi-structured interview schedules and observation guide from self-help group officials and members of the self-help groups. Sampling was done using both probability and nonprobability sampling. In this study, the researcher found out that, there was a lot of information about the diverse nature of self-help groups with the majority being formed along economic lines while a few being socially inclined. It was also clear that a majority of the self-help groups were formed by individuals through self-effort while a few as a result of NGO motivation. The groups consisted of mostly 15-20 members who meet periodically at fixed intervals to discuss, reflect on and find solutions to their socio-economic issues.

\section{Methodology}

Research Design: In this research, descriptive design was applied to examine the effects of women participation in the SHGs for their socio- economic empowerment. Descriptive research design was used in this study because of its appropriateness in establishing relationships between variables and facilitating the collection of information for determining the population parameters. It also had elicited the most complete responses from the selected women participating in the selected self-help groups.

Study Area: This study was carried out in Urban West Region of Unguja. This region has three districts namely; West a District, West B District and Urban District. This area was selected due to the nature of the study undertaken where appropriate stakeholders who were expected to have much information on issues of SHGs live.

Study Population: The population of this study was 878 women who belong to the ten (10) self-help groups in Urban West Region of Unguja. These groups are; Kina Mama Tujenge; i) 'Tuwena Moyo' ii) 'Wema Hauozi' iii) 'Rehema ya Mungu' iv) 'Jitihada' v) 'Kwa Pamoja Tunaweza' vi) 'Tupendane' vii) 'Umoja ni Nguvu' Viii) 'Mama ni Mama' ix) Kina Mama Tujenge and; $x$ ) Tuwe na Imani. 
Sample Techniques and Sample Size: The researchers employed probability and non-probability sampling to select a total sample size of 90 respondents from the mentioned SHGs. All were given questionnaires aimed at seeking their responses. This minimum selection was based on the fact that, sufficient minimum size of samples may lead to proper collection and management of data which is contrary to the selection of vast sample size.

Data Collection Tool: Self-administered questionnaires were distributed to the respondents. The researchers used closed ended questions with a five (5) point Likert scale questions.

Data Analysis: This study employed both descriptive and inferential statistical tools of analysis. Through descriptive such as mean scores, standard deviation, frequencies and percentages and through inferential t-test was used to measure the difference in annual income before and after women participating in social help groups in Unguja.

\section{Study Findings}

\subsection{Demographic Data of the Respondents}

Personnel characteristics of respondents had very significant role to play in expressing and giving the responses about the problem, keeping this in mind, in this study a set of personal characteristics namely, age, sex, education, designation and work experiences of the 90 respondents were examined and are hereunder:-

Table 1. Demographic Data of the Respondents.

\begin{tabular}{|c|c|c|c|}
\hline Variable & Category & Frequency & Percentage (\%) \\
\hline \multirow{4}{*}{ Age } & $18-27$ & 7 & 7.8 \\
\hline & $28-37$ & 37 & 41.1 \\
\hline & $38-47$ & 39 & 43.3 \\
\hline & 48 and above & 7 & 7.8 \\
\hline \multirow{4}{*}{ Marital status } & Married & 60 & 66.7 \\
\hline & Single & 15 & 16.7 \\
\hline & Divorced & 6 & 6.6 \\
\hline & Widow & 9 & 10.0 \\
\hline \multirow{6}{*}{ Education } & Primary & 3 & 3.3 \\
\hline & Secondary & 3 & 3.3 \\
\hline & Certificate & 6 & 6.7 \\
\hline & Diploma & 54 & 60.0 \\
\hline & Degree & 21 & 23.3 \\
\hline & Master and above & 3 & 3.3 \\
\hline \multirow{6}{*}{$\begin{array}{l}\text { Experience of } \\
\text { being in SHGs }\end{array}$} & Less than 1 year & 4 & 4.4 \\
\hline & 1 years & 4 & 4.4 \\
\hline & 2 years & 12 & 13.3 \\
\hline & 3 years & 57 & 63.3 \\
\hline & 4 years & 8 & 8.9 \\
\hline & 5 years and above & 5 & 5.6 \\
\hline
\end{tabular}

Source: Field data, 2021

By age, Table 1 shows an overwhelming number of the respondents (84.4 percent) fell under age group of 28 to 47 years. This age range is the most common one for people with family members working hard to sustain their families in Zanzibar. It is common in Zanzibar that this age bracket is always given priority of accessing financial support from different sources such as social help groups. This age provided relevant information for this study.

Also, a marital status of the respondents showed that, more than half $(66.7 \%)$ of the respondents were married. This clearly indicated that, most of the respondents who were involved in answering questions in this study were married which was the targeted population of the researchers to get the view of the people who were taking care of their families and joined SHGs in Unguja.

Through education, it seems that most of the respondents were educated up to diploma and degree levels with (60) and $(23.3 \%)$ respectively. This implied that, the number of the respondents who had attained higher education was very small; only (23.3\%) were educated up to degree and above, while the remaining $(73.3 \%)$ I had education qualification below degree level.

Finally, Table 1 shows that, $(63.3 \%)$ of the respondents had 3 years of working experience in SHGs and only (8.9) and $(5.6 \%)$ of the respondents had working experience of 4 and 5 years and above in the SHGs respectively. And the remaining percentage had work experience of below 3 years. This implied that, the researchers had balanced the collected information from this SHGs information.

\subsection{An Account of the Difference in Income Before and after Women Participating in the Self-Help Groups}

The researchers examined the difference between the income of the women who participated in the self - help groups before and after joining the SHGs. Both descriptive statistics such as (frequencies and percentages) and inferential statistical such as (independent sample t-test) were used to analyze the data for this objective. The researchers engaged respondents whose responses were used to answer this question clearly and the results were summarized as follows:-

a. Kind of SHGs groups involved

In this part of the study, the researchers were interested in finding out the kind of SHGs the respondents were involved in. Where different kinds of SHGs activities were mentioned and respondents were required to select. The results were clearly summarized in Table 2.

Table 2. Kind of SHGs activities respondents were involved in.

\begin{tabular}{lll}
\hline SHGs activities & Frequency & Percent \\
\hline Agricultural production & 34 & 37.8 \\
Hand crafts & 16 & 17.8 \\
Shop keeping & 13 & 14.4 \\
Business enterprises & 17 & 18.9 \\
Others & 10 & 11.1 \\
Total & 90 & 100.0 \\
\hline
\end{tabular}

Source: Filed Data, 2021

Table 2 on the kinds of SHG activities the respondents were involved in and the results of the study showed that, out of 90 respondents $34 \quad(37.8 \%)$ selected agricultural production whereby 16 respondents equal to $(17.8 \%)$ selected handcraft activities, while 13 respondents equal to (14.4\%) selected business enterprises and those who selected others 
were 10 respondents equal to (11.1\%). Therefore, this clearly shows that, most of respondents who were involved in this study were engaged in agricultural production because it was selected by largest number of respondents.

The findings of this study were supported by the results of Deogratiaset. al, [5]. which discussed about Social Functionality of Self Help Groups in Tanzania. Primary data was collected through interview and questionnaires. The results found that, 42.9 percent of the total respondents reported to have been engaged in farming activities. This were followed by those who kept livestock, petty business and other economic activities which represent 29.7 percent, 19.7 percent and 7.7 percent respectively. Among those belonged to other economic activities, some were employed in formal sector while others did not perform any significant economic activity due to old age and different disabilities and they depended on donations and grants.

b. Perception on income achievement before participating in $\mathrm{SHG}$ projects

In this part of the study, the researchers were interested in appreciating the perception of respondents on income achievement before participating in the self-help groups. Here, respondents were required to indicate whether income achievement was effective, very effective, moderate, minimum or not effective. The results are clearly summarized in Table 3.

Table 3. Perception on income achievement before participating in SHG projects.

\begin{tabular}{lll}
\hline Attributes & Frequency & Percent \\
\hline Effective & 2 & 2.2 \\
Very effective & 4 & 4.4 \\
Moderate & 60 & 66.7 \\
Minimum & 19 & 21.1 \\
Not effective & 5 & 5.6 \\
Total & 90 & 100.0 \\
\hline
\end{tabular}

Source: Filed Data, 2021

Table 3 presents findings on the perception about income achievement before participating in SHG projects. The results showed that, out of the 90 respondents, 2 respondents equal to $(2.2 \%)$ replied effective, whereby 4 respondents equal to $(4.4 \%)$ replied very effective activities, while 60 respondents equal to $(66.7 \%)$ replied moderate, but 19 respondents equal to $(21.1 \%)$ replied minimum and those who replied not effective were 5 respondents equal to (5.6\%). Therefore, this clearly shows that, perception on income achievement before participating in SHG projects was moderate since more than half $(66.7 \%)$ of the respondents replied affirmatively. This clearly indicated that, before joining the SHGs, the income of the respondents was not so good, not bad but moderate. This may explain why they struggled to join SHGs to improve their income levels.

These results were supported by the results of the study conducted by Ramola [18], whose study found out that, most of the beneficiaries agreed that, they were getting some satisfaction after joining the SHGs like (73\%) while there were very few respondents who disagreed (9.5\%) and strongly disagree $(5.5 \%)$ who were not satisfied. Also, she found out that, the income of her respondents was less than $10,000 /=$ which was equivalent to $(47 \%)$ compared to other income groups. This means that, there were more people living below poverty line in the District of Dehradun.

c. Perception on income achievement after participating in $\mathrm{SHG}$ projects

In this part of the study, the researcher was interested in finding out the perception of the respondents on income achievement after participating in the self-help projects. Here, respondents were required to indicate whether income achievement after joining SHGs was effective, very effective, moderate, minimum or not effective. The results were clearly summarized in Table 4.

Table 4. Perception on income achievement after participating in SHG projects.

\begin{tabular}{lll}
\hline Attributes & Frequency & Percent \\
\hline Effective & 59 & 65.6 \\
Very effective & 15 & 16.7 \\
Moderate & 6 & 6.7 \\
Minimum & 5 & 5.6 \\
Not effective & 5 & 5.6 \\
Total & 90 & 100.0 \\
\hline
\end{tabular}

Source: Filed Data, 2021

Results in Table 4 on perception about income achievement after participating in SHG projects, showed that, out of 90 total respondents, 59 respondents equal to $(65.6 \%)$ replied effective, yet 15 respondents equal to $(16.7 \%)$ replied very effective activities, while 6 respondents made $(6.7 \%)$ replied moderate, but 5 respondents equal to $(5.6 \%)$ replied minimum and those who replied not effective were 5 respondents equal to (5.6\%). Therefore, this clearly showed that, perception on income achievement after participating in SHG projects was effective since more than half of the respondents almost (65.6\%) replied effective. This implied that, most of respondents after joining the SHGs, their income levels improved compared to the situation before joining SHGs.

\section{d. Monthly earning before participation in SHGs}

In this part of the study, the researchers were interested in finding out the monthly earning before participation in the self-help projects where respondents were required to indicate whether the participants earned less than 100,000/=, between 100,000 and $200,000 /=; 200,000-300,000 /=$; $300,000-400,000 /=$ or 400,000 and above. The results are clearly summarized in Table 5.

Table 5. Monthly earning before participation SHGs.

\begin{tabular}{lll}
\hline Income level (T-sh) & Frequency & Percent \\
\hline Less than 100,000 & 21 & 23.3 \\
$100,000-200,000$ & 57 & 63.3 \\
$200,000-300,000$ & 4 & 4.4 \\
$300,000-400,000$ & 4 & 4.4 \\
400,000 above & 4 & 4.4 \\
Total & 90 & 100.0 \\
\hline
\end{tabular}

Source: Filed Data, 2021

Table 5 is illustrative of the monthly earnings before 
participation in SHGs projects, results showed that, out of 90 respondents, 21 respondents equal to $(23.3 \%)$ earned less than 100,000 , whereby 57 respondents equal to $(63.3 \%)$ earned $100,000-200,000$, while 4 respondents equal to $(4.4 \%)$ earned $200,000-300,000$, but 4 respondents equal to (4.4\%) earned $300,000-400,000$ and those who earned 400,000 and above were 4 respondents equal to $(4.4 \%)$. Therefore, this clearly showed that, most of respondents before joining SHG projects, their monthly income was between $100,000-200,000$ since more than half of respondents, $(63.3 \%)$ replied affirmatively. This is implied that, before joining SHGs, monthly earning of the respondents was not good.

These results were supported by the results from the study conducted by Karthik [19], on the Impact of Self Help Groups in Economic Empowerment of Rural Women. He used 100 samples from three villages. Average, percentage and paired t' Test were used for data analysis. He found out that, of 100 respondents, regarding income before joining the group, $(13 \%)$ of the respondents said no income, $(45 \%)$ respondents said income was less than Rs. $3000,(31 \%)$ of the respondents said income was between Rs. 3000 and 5000, (6\%) marks Rs. 5000-7000 and (5\%) opted for more than Rs. 7000. For income after joining the group, (10\%) said less than Rs. 3000, (33\%) said Rs. 3000-5000, (28\%) said Rs. 5000- 7000 and (29\%) said more than Rs. 7000.

\section{e. Monthly earnings after participation in SHGs}

In this part of the study, the researchers were interested in finding out the monthly earning after participation in the selfhelp projects. Here, respondents were required to indicate whether they earned less than $100,000 /=, 100,000$ $200,000 /=, 200,000-300,000 /=, 300,000-400,000 /=$ or 400,000 and above. The results were clearly summarized in Table 6 .

Table 6 is about monthly earnings after participation in SHGs projects. Results showed that, out of 90 respondents, 5 respondents equal to $(5.6 \%)$ earned less than $100,000,10$ respondents equal to $(11.1 \%)$ earned $100,000-200,000$, while 7 respondents equal to $(7.8 \%)$ earned $200,000-$ 300,000 , but 7 respondents equal to $(7.8 \%)$ earned $300,000-$ 400,000 and those who earned 400,000 and above were 61 respondents equal to $(67.8 \%)$. Therefore, this clearly showed that, most of the respondents after joining the SHG project, their monthly income was 400,000 and above since it was selected by more than half of the respondents, (almost $67.8 \%$ ). This clearly indicated that, monthly earnings of respondents after joining SHGs were improved in advance since their earnings fell between 400,000 and above where most of members got morale of joining SHGs.

Table 6. Monthly income earnings after participation in SHGs.

\begin{tabular}{lll}
\hline Income level & Frequency & Percent \\
\hline Less than 100,000 & 5 & 5.6 \\
$100,000-200,000$ & 10 & 11.1 \\
$200,000-300,000$ & 7 & 7.8 \\
$300,000-400,000$ & 7 & 7.8 \\
400,000 above & 61 & 67.8 \\
Total & 90 & 100.0 \\
\hline
\end{tabular}

Source: Filed Data, 2021

\subsection{Independent Sample T-Test}

T-tests are used when a researcher has two groups (for example males and females) or two sets of data (before and after) and wishes to compare the mean score on some continuous variables [20]. For the case of this study, the researchers compared two sets of data of income before and after women participating in self-help group projects as a strategy of empowerment.

Therefore, the independent t-test was computed in order to find out whether there were differences in income before and after participating in self-help group projects and the result were obtained. They are depicted in Table 7 and Table 8 .

Table 7. Group Statistics.

\begin{tabular}{lllll}
\hline & Source of Income & N & Mean & Std. Deviation \\
\hline \multirow{2}{*}{ Income } & Before participating in SHG & 39 & 2.0769 & .41630 \\
& After participating in SHG & 51 & 3.9501 & .27760 \\
\hline
\end{tabular}

Table 8. Independent Sample Test.

\begin{tabular}{|c|c|c|c|c|c|c|c|c|c|c|}
\hline & & \multicolumn{2}{|c|}{$\begin{array}{l}\text { Levene's Test for } \\
\text { Equality of Variances } \\
\end{array}$} & \multicolumn{7}{|c|}{ t-test for Equality of Means } \\
\hline & & \multirow[t]{2}{*}{$\mathbf{F}$} & \multirow[t]{2}{*}{ Sig. } & \multirow[t]{2}{*}{$\mathbf{t}$} & \multirow[t]{2}{*}{ Df } & \multirow{2}{*}{$\begin{array}{l}\text { Sig. } \\
\text { (2-tailed) }\end{array}$} & \multirow{2}{*}{$\begin{array}{l}\text { Mean } \\
\text { Difference }\end{array}$} & \multirow{2}{*}{$\begin{array}{l}\text { Std. Error } \\
\text { Difference }\end{array}$} & \multicolumn{2}{|c|}{$\begin{array}{l}95 \% \text { Confidence Interval } \\
\text { of the Difference }\end{array}$} \\
\hline & & & & & & & & & Lower & Upper \\
\hline \multirow{2}{*}{ Income } & Equal variances assumed & 3.685 & .024 & 1.568 & 88 & .001 & .43471 & 1.17376 & -.22718 & .48508 \\
\hline & Equal variances not assumed & & & 1.531 & 73.420 & .001 & .43471 & 1.17325 & -.22618 & .48407 \\
\hline
\end{tabular}

The findings of the independent-sample t-test indicated that, there was a significant difference between before participating in SHGs $(\mathrm{M}=2.0769, \mathrm{SD}=0.416)$ and after participating in SHGs $(\mathrm{M}=3.9501, \mathrm{SD}=0.278 ; \mathrm{t} \quad(88)=1.568, \mathrm{p}=0.001$, two tailed.). These implied that, women after participating in SHGs, their income changed from one level to another level. These findings also were supported by the descriptive findings as seen earlier in this section. These finding were aligned with Nkuru [21], they conducted a study on SACCOS and members' expectation. They found out that, if SACCOs were well managed, they had the potential to bring about income differentials for the participants. 


\section{Conclusion}

On examining the difference of income before and after of the women participating in the self-help projects, it was concluded that, most of respondents who were involved in this study got their source of income from the self - help groups (SHGs) because it was selected by more $(60 \%)$ of the respondents. Also, the study concluded that, the perception on income achievement before participating in SHG projects was moderate and the perception on income achievement after participating in SHG projects was effective since more than half of respondents $(65.6 \%)$ replied on moderate.

In addition, the study also concluded that, most of the respondents before joining SHG projects had their monthly income between $100,000-200,000$ and most of the respondents after joining SHG projects, their monthly income rose up to 400,000 and above since it was selected by more than half of respondents $(67.8 \%)$.

\section{Recommendations}

Based on the results, it may be acclaimed that, the functioning of SHGs activities are contributing significantly in increasing the status and livelihood options of women in every sphere so as to make the women lead both empowered and changed lives. Therefore, it was recommended that, the responsible institutions should be capitalized and promoted to enhance the status of women in society.

SHGs are a vanguard and conduit of both social change and economic empowerment in most societies around the world. Therefore, the Revolutionary Government of Zanzibar and all other key stakeholders should support them both politically and financially as to enable them achieve their ultimate goals.

The government and NGOs which were working in the area and emphasizing the formation of SHGs should improve living and working conditions of the women and should focus on increasing and improving women's educational levels. The improved education system in rural areas would automatically lead to increased participation in SHGs.

\section{References}

[1] Fox, L. and Romero, C. (2017). In the Mind, the Household or the Market? Concepts and Measurement of Women's Economic Empowerment. World Bank Group.

[2] United Nations. (2014). World survey on the role of women in development: Women's control over Economic resources and access to financial resources, including micro-finance. Department of Economic and Social Affairs, Division for the Advancement of Women: New York.

[3] Sarania, R., (2014), Employment and Agro-based Industries: A study on women self Help Groups (SHGSs) in Baksa District of Assam in Dinesh Das (ed.) prospects and problems of AgroBased Industries in Assam, first Edition, N. L. Publications, Assam, India.

[4] Yssaad, L. and Ferrao, V. (2019). Self-employed Canadians:
Who and Why? Statistics, Canada.

[5] Deogratias B, (2014). Social Functionality of Self Help Groups in Tanzania. Journal of Business Administration and Education. Volume 5, Number 2, 2014, 99-136.

[6] Fakih, A. O. (2015. Agricultural Services Support Programme and Socioeconomic Empowerment of Rural Women in Zanzibar, Tanzania Agricultural Services Support Programme and Socioeconomic Empowerment of Rural Women in Zanzibar, Tanzania. SOKOINE UNIVERSITY OF AGRICULTURE.

[7] Tanzania Media Women's Association-Zanzibar (2018). Women Empowerment in Zanzibar (WEZA II) in Collaboration with Milele Zanzibar Foundations.

[8] Zanzibar Planning Commission (2019). Evaluation of Zanzibar Vision 2020, ZPC Publication, Zanzibar.

[9] Durkheim, Emile (1893). From the division of social work: study on the organization of higher societies, Paris: F. Alcan.

[10] Fawcett, S. B., Paine-Andrews, A., Francisco, V. T., Schultz, J. A., Richter, K. P., Lewis, R. K., Harris, K. J., Williams, E. L., Berkley, J. Y., Lopez, C. M. and Fisher, J. L. (1996). Empowering community health initiatives through evaluation. In (eds.) D. Fettermann, A. S. Kaftarian and A. Wandersman, Empowerment evaluation: Knowledge and tools for selfassessment and accountability. Beverly Hills: Sage.

[11] Mancur, O., (1965). The Logic of Collective Action, Cambridge: Harvard University Press.

[12] Nayak, A. K \& Panigrahi, P. K, (2020). Participation in SelfHelp Groups and Empowerment of Women: A Structural Model Analysis. Journal of Developing Areas, Tennessee State University, College of Business, vol. 54 (1), pages 19-37, January-M.

[13] Joshi, G. (2019), An analysis of women's self-help groups' involvement in microfinance program in India. Rajagiri Management Journal, Vol. 13 No. 2, pp. 2-11.

[14] Alemu, S. H., Kempen, L. V \& Ruben, R (2018). Women Empowerment through Self-Help Groups: The Bittersweet Fruits of Collective Apple Cultivation in Highland Ethiopia, Journal of Human Development and Capabilities, 19: 3, 308330 .

[15] Mbai, S. N (2017). Influence of Self-Help Groups Activities on the Women Empowernment in Rural Kenya: A Case of Miambani Ward, Kitui County.

[16] Badejo, A. F., Majekodunmi, A. O., Kingsley, P. (2017). The impact of self-help groups on pastoral women's empowerment and agency: A study in Nigeria. Pastoralism 7, 28.

[17] Okello. N. L (2014). Women's Self Help Groups: A Study of their Characteristics and Performance in Saboti Constituency, Trans-Nzoia County (unpublished master's thesis, Department of Sociology and Social Work, University of Nairobi).

[18] Ramola, K. S. and Neeraj, K. (2015). Perception of Beneficiaries Regarding the Micro Finance To the Self Help Groups (SHGs). Asian Resonance. VOL.-IV, ISSUE-II.

[19] Sharma, S., Thakur, K. S. and Singh, D. V. (2020). Role of Self Help Groups on Women Economic Empowerment. PAIDEUMA JOURNAL Vol XIII Issue II, Issn No: 00905674. 

Participating in the Self-Help Groups in Urban West Region of Unguja

[20] Pallant, J. (2016). SPSS Survival Manual (6th ed.). New York, United States of America: McGraw-Hill.
[21] Nkuru, F. N. (2015). Factors Affecting Growth of SACCOS within the Agricultural Sector in Kenya: A Case of Meru Farmers SACCOS. G. J. C. M. P., Vol. 4 (1): 34-45. 